\title{
Digital Transformation Trends in Russian and Foreign Companies
}

\author{
Bostoganashvili E.R. ${ }^{1, *}$ Nigmatullina I.V. ${ }^{2}$ Kashapova R.A. ${ }^{2}$
}

\author{
${ }^{1}$ MGIMO University, Moscow, Russia \\ ${ }^{2}$ Financial University under the Government of the Russian Federation, Ufa Branch, Ufa, Russia \\ *Corresponding author. Email: magreg76@yandex.ru
}

\begin{abstract}
Nowadays, digital revolution is taking place in different countries around the world. Many private and stateowned companies started to implement various digital technologies to increase the efficiency of their business processes and, at the same time, to reduce their costs. The most widely used digital technologies in Russia and foreign countries (USA, Germany, Japan, China, etc.) are: cloud technologies, artificial intelligence, ecommerce programs, blockchain. The authors provide a detailed overview and effects of using these four digital technologies. The authors also compare the main trends of digital transformation in Russian and American companies, and conclude with recommendation to use foreign companies' experience adapting it to Russian specifics.
\end{abstract}

Keywords: digital transformation, digitalization, artificial intelligence, cloud technologies, electronic

commerce, blockchain

\section{INTRODUCTION}

Today, highly developed countries around the world have entered the fourth industrial revolution. Information and its processing are the main characteristics of the modern world. The interaction of companies and people is becoming too complicated. Digital technologies and their implementation in business and everyday life will help participants to interact more efficiently and correctly. If companies want to survive in extremely complex markets, they must incorporate digital technology into their business processes.

\section{METHODOLOGY}

First of all, we explain what we mean by digital transformation. Further, we identify main platforms and technologies associated with digital transformation.

Secondly, we identify main digital transformation trends in Russian and foreign companies.

Finally, based on the obtained results, we give recommendations for Russian companies, which could be helpful in improving their business processes.

\section{RESULTS AND DISCUSSION}

In general, digital transformation of companies is the process of integrating digital technologies into business processes of a company. Speaking about digital transformation, we mean not only high-tech equipment and computer programs that are used in the company; fundamental changes need to be made in corporate governance, corporate culture, technological chains, marketing policies and external communications $[1,2]$. Digital transformation is aimed at achieving several goals that are necessary for the successful functioning of the company [3, 4]; these are:

- improving labor efficiency;

- increasing customer satisfaction with the company's products and services;

- improving the business processes of the company;

- increasing the speed of decision-making within the company;

- expanding partnerships with companies around the world;

- reducing current expenses of the company;

- creating new products with higher added value;

- getting a new reputation: business environment begins to consider that this company is progressive and high-tech.

Let us consider the term of digitalization. Digitalization is the use of digital technologies in order to increase the efficiency of the company's current business processes [5, 6]. Comparing "digital transformation" and "digitalization" shows that digital transformation of a company consists of two aspects: 1) the introduction of high-tech equipment and software, 2) and fundamental changes in the company's business and corporate areas. Thus, "digitalization" means the mere introduction of high-tech equipment and software in the company, without any other changes. 
Today, digital transformation spreads not only to business entities. Russia and all highly developed countries are carrying out the digital transformation in different sectors of their economies, such as industry, energy, retail, banking and financial services, public sector, etc. [7].

To introduce digital transformation in its business activities, a company need to solve a very difficult task to create a unified information system, which will become the environment for various digital platforms and technologies that can interact with each other [8]. There are four main groups of such platforms and technologies:

1. Modern cloud technologies allow to store business and corporate data on external servers provided by IT companies [9]. This solution is very beneficial for users: they have round-theclock access to corporate and business data, and server maintenance costs are not high.

There are several cloud technologies for business:

- SaaS (software as a service) - this software does not require installation on a computer. This group of programs includes various types of electronic document management systems and messaging applications;

- IaaS (infrastructure as a service) - these are various cloud technologies for different purposes;

- PaaS (Platform as a Service) - using these platforms allow the user to create programs and services without installing special equipment or software.

In 2017, the cloud business systems market amounted to 150 billion US dollars. According to forecasts, it will be about 300 billion US dollars in 2021 [10].

2. Artificial intelligence technologies are created to help people solve various problems. Companies use these technologies to solve problems connected with data processing. It is expected that global spending on artificial intelligence and cognitive technologies in 2020 will amount to about 50 billion US dollars, and 100 billion US dollars by 2030 [11].

Currently, large Russian companies are investing hundreds of millions of dollars in the development and implementation of artificial intelligence. By 2020, the volume of the Russian market of artificial intelligence and machine learning will increase to 28 billion rubles [12]. The main Russian companies that are rapidly introducing artificial intelligence technologies into their business processes are large financial and insurance public and private corporations; some Russian retailers are also introducing artificial intelligence into their business systems.

The Russian financial sector is a leader in the use of artificial intelligence among other Russian industries. Artificial intelligence technologies help solve various problems in the financial sector, such as:

- reduction of current expenses;

- minimization of various risks;

- assessment of a borrower's creditworthiness;
- $\quad$ assistance in the development of forecast models that describe the behavior of various economic indicators.

For example, Uralsib Bank uses artificial intelligence to analyze data about its customers, which allows to identify more accurately banking services that are needed for a particular client [12].

Artificial intelligence is also implemented in retail companies and help them to solve various problems specific to the retail industry, such as:

- improving the quality of customer service;

- optimization of supply chains;

- analysis and inventory of stocks;

- reduction of company costs;

- forecasting demand for products and services.

For example, M.Video introduced artificial intelligence with machine learning into its first-line customers support system [13], which is used by the employees if they do not have enough information in the offices, shops or warehouses, where they work. This artificial intelligence system is a self-learning robot that uses a large amount of information for training based on the employees' requests. It is able to analyze and recognize text messages, communicate with customers in a special chat, understand the essence of the request, identify people who must fulfill incoming requests, and check the quality of employees' work.

Artificial intelligence is also successfully used in insurance, where it helps to:

- manage e-document flow;

- process customer data;

- $\quad$ analyze risks;

- fight against fraudsters and unscrupulous contractors;

- determine personalized insurance services for clients;

- determine the optimal algorithm for the distribution of insurance payments.

Today, AlfaStrakhovanie implements artificial intelligence to solve the main problem of the insurance market - fraud in the claim settlement. Analyzing insured events covered by third party only car insurance (OSAGO) and clients' data, the artificial intelligence system helps to reveal feasible fraud among dubious cases. Based on obtained results, the company's analysts can control better such insured events $[13,14]$.

3. Computer programs for e-business. Electronic business (e-business) is a commercial activity carried out using computers connected through a global network $[15,16]$. E-business programs connect companies to each other (B2B, Businessto-Business) or connect companies with consumers (B2C, Business-to-Consumer). We should note that there are also other programs that connect, for example, the company and its employees (B2E, Business-to-Employee), the company and the government (B2G, Business-to -Government), etc. [17].

E-business is beneficial for its participants $[15,18]$ : 
- global coverage of all consumers and manufacturers, facilitating the search for the right seller or buyer;

- $\quad$ ability to work continuously throughout the year; such a schedule allows an unlimited circle of consumers at any time convenient for them to order the goods and services they need;

- lower operating costs compared to "real-life" stores;

- automated inventory management (software with artificial intelligence elements) ensure a more balanced and efficient use of working capital based on the dynamics of changes in the company's inventory;

- a more effective marketing policy developed using software systems, which process and analyze huge amounts of information about consumers.

4. Blockchain technologies. The blockchain is a distributed database of records that are linked to each other, validated and easy to verify. In addition, these records can include all possible types of information (from monetary transactions to completed contracts). The most important condition for the correct operation of a system based on blockchain technologies is that the information in these records must be verified and reliable. Blockchain technology has great potential; it can be implemented both in the business processes of the company and in the financial architecture of the country. Many analysts and economists believe that the blockchain provides great economic benefits to all participants [19]. Currently, Sberbank, UAC (United Aircraft Corporation), Aeroflot, Russian Coal, ForteInvest are successfully implementing a blockchain-based electronic document management system in their business processes. VTB Bank successfully issues electronic banking guarantees on the Masterchain platform [20].

Blockchain can be used in different sectors of economy and helps to reduce current expenses, increase revenues, increase capital, and positively change the company's social reputation. In the near future, companies will incorporate blockchain technology into their business processes to reduce their current expenses [21, 22].

Embedding blockchain technologies in a particular sector of the economy is determined by four key factors [19]: a) development and improvement of the blockchain; b) digitalization of assets; c) standards and regulations; d) degree of interaction of economic actors in the industry.

Before starting full digital transformation, a company should develop a digital transformation strategy; the company's departments and employees should be involved in improving business processes. The company should also identify digital technologies and platforms that most closely meet its needs and objectives of the company. Digital transformation should be performed by a motivated team of highly qualified professionals [2].
At this stage of global development, the leading countries entered the fourth industrial revolution in the format of the digital economy [23]. Many US companies in order to obtain unique technological and competitive advantages and minimize costs that do not lead to a decrease in labor productivity, transform production technologies, products and services into digital formats [24]. Thus, companies are orienting their production processes to new operating models, becoming more and more digitalized and robotized.

The main digital transformation trends of US companies are:

- introducing digital platforms that allow to create parallel production chains, consisting of digital production and business models;

- embedding virtual augmented reality systems in production and management processes;

- introducing blockchain in business processes;

- using artificial intelligence systems to more successfully solve a number of economic tasks;

- personnel training with the use of different digital and interactive learning courses;

- increasing use of robots and robotic systems in production processes;

- using the Internet of things to solve a number of economic and technological tasks;

- using nanotechnology, quantum chemistry, digital biology to reduce production costs.

These digital transformation trends are also typical for European, Australian, Canadian, Japanese and Chinese companies.

In Russia, main digital transformation trends include:

- implementation of Big Data analysis systems and predicative analytics. The speed and quality of big data processing has a significant impact on the efficiency of companies. Predictive analytics is used to analyze large amounts of data and build high-quality predictive models;

- use of blockchain technology, which allows to reduce the risks of fraud or unfair use of information;

- use of optical character recognition (OCR) systems that facilitate the company's document flow management and accelerate business processes. This technology is able to replace a person during the process of receiving, analyzing and checking documents;

- use of the Internet of things, in particular to collect information for its further processing;

- use of virtual and augmented reality VR / AR to reduce the production and business cost by working process modelling;

- use of artificial intelligence systems;

introduction of chat bots running inside a multifunctional application that can simulate text and speech into company's business processes for support tasks, requests processing and information search.

Figure 1 shows the most popular digital technologies used by Russian companies in 2018 . 


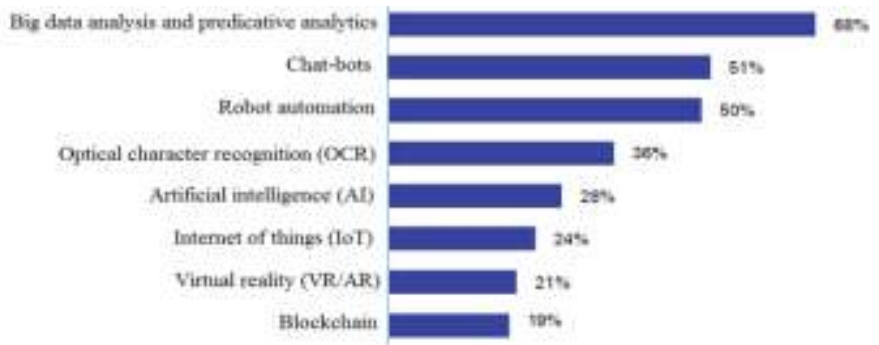

Figure 1 Most popular digital technologies used by Russian companies in 2018

Source: [25].

Table 1 presents digital technologies used in Russian companies within different industries.

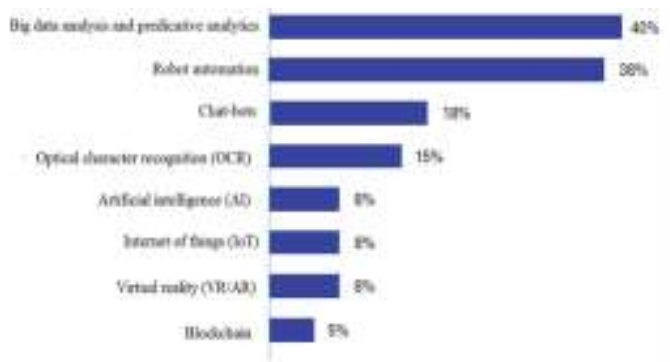

Figure 3 The most cost-effective digital technologies in Russian companies in 2018

Source: [25].

According to Figure 3, in 2018, the biggest economic effect was obtained using big data analysis and predicative analytics technologies.

\section{Table 1 Digital technologies in Russian companies}

\begin{tabular}{|c|c|c|c|c|c|c|c|c|}
\hline Technology & In the whole & Retail & Telecom & Financial institutes & Metallurgy & II & Oil and gas & Trasport \\
\hline Biz data & $68 \%$ & $55 \%$ & $100 \%$ & $84 \%$ & $67 \%$ & $100 \%$ & $50 \%$ & $14 \%$ \\
\hline Chat-bots & $51 \%$ & $50 \%$ & $75 \%$ & $80 \%$ & $33 \%$ & $40^{\circ} \%$ & $50 \%$ & $29 \%$ \\
\hline Robot automat & tion $50 \%$ & $40 \%$ & $100 \%$ & $56 \%$ & $83 \%$ & $20 \%$ & $50 \%$ & $14 \%$ \\
\hline OCR & $36 \%$ & $20 \%$ & $25 \%$ & $56 \%$ & $67 \%$ & $1 \%$ & $50 \%$ & $14 \%$ \\
\hline AI & $28 \%$ & $5 \%$ & $75 \%$ & $40 \%$ & $17 \%$ & $80 \%$ & $25 \%$ & $1 \%$ \\
\hline loT & $24 \%$ & $15 \%$ & $100 \%$ & $12 \%$ & $50 \%$ & $20 \%$ & $28 \%$ & $29 \%$ \\
\hline VR/AR & $21 \%$ & $20 \%$ & $25 \%$ & $16 \%$ & $33 \%$ & $40 \%$ & $25 \%$ & $14 \%$ \\
\hline Blockchain & $19 \%$ & $20 \%$ & $25 \%$ & $32 \%$ & $1 \%$ & $20 \%$ & $1 \%$ & $1 \%$ \\
\hline
\end{tabular}

Source: [25].

Figure 2 shows companies' expectations of implemented digital technologies.

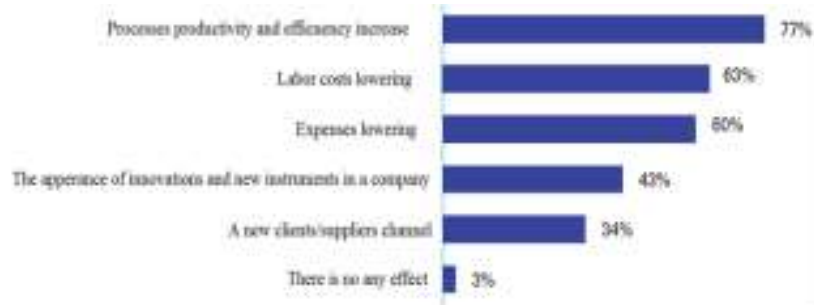

Figure 2 Expectations of Russian companies Source: [25].

As shown from Figure 2, most Russian companies expected that introducing digital technologies in their business and production processes will increase operational efficiency and reduce operating costs of the company.

\section{CONCLUSION}

In general, both Russian and foreign companies have similar directions of digital transformation of their business. Using the foreign experience in the field of digital technologies, Russian companies can more efficiently switch to new "digital" tracks of its functioning, but such experience should be adapted to domestic specifics. Russian companies should invest more in a new digital equipment and software, which facilitate the analysis of a huge amounts of information obtained from their business activity.

Due to use of personal data, digital transformation of companies and sectors of the country's economy should be controlled by the government, which, in particular, should develop and adopt laws on personal data security. 
[11] The St. Petersburg International Economic Forum, Artificial Intelligence (AI): where is the limit? (2017), available online: https://tass.ru/pmef2017/articles/4271535

[12] T. Khisamov, Technology race: how Artificial Intelligence helps business (2017), available online: https://www.forbes.ru/tehnologii/354727-gonkatehnologiy-kak-iskusstvennyy-intellekt-pomogaetbiznesu

[3] M. Grigoriev, Digital business transformation: how and why to change in the digital era (2018), available online: https://vc.ru/flood/42092-cifrovayatransformaciya-biznesa-kak-i-zachem-menyatsya-vdigital-eru

[4] Croc, Digital transformation (2020), available online:

https://www.croc.ru/eng/solution/services/digital/

[5] R. Sivaraman, Digitalization 101: The Means to a Successful Enterprise Outcome (2017), available online: https://www.automation.com/enus/articles/2017/digitalization-101-the-means-to-asuccessful-enter

[6] Digitalization is a fundamental trend: interview with A. Belevtsev, director for digital transformation at Gazprom Neft, Siberian Oil 4/151 (2018) 26-29, available online: https://www.gazpromneft.ru/press-center/sibneft-online/archive/2018may/1589542/

[7] "Digitalization of economic sectors and digital business strategies" - Larisa Lapidus discussion at the "Digitalization-2018" forum" (2018), available online: https://digital.msu.ru/цифровизация-отраслейэкономики-и-ц/

[8] P. J. Mudialba, The Impact of Cloud Technology on the Automation of Businesses, 2016 International Conference on Platform Technology and Service (PlatCon), Jeju, 2016, 1-4. DOI: 10.1109/PlatCon.2016.7456831

[9] D. G. Smirnov, Cloud technologies in business, Economical science magazine "Investment evaluation" 3(11) (2018) 35-44.

[10] Gartner, Gartner Says Worldwide Public Cloud Services Market to Grow 18 Percent in 2017 (2017), available online: https://www.gartner.com/en/newsroom/pressreleases/2017-02-22-gartner-says-worldwide-publiccloud-services-market-to-grow-18-percent-in-2017
[13] Croc, M.video-Eldorado Employs CROC's Bot to Supervise First-Line Technical Support (2019), available online: https://www.croc.ru/eng/news/detail/82918/

[14] ComNews, Artificial Intelligence Penetrates Insurance (2019), available online: http://www.comnews.ru/content/121134/2019-07-

31/iskusstvennyy-intellekt-pronikaet-v-strahovanie

[15] Ecommerce Platforms, E-commerce Definition. What is E commerce? Ecommerce Explained for 2019 (2019), available online: https://ecommerce-platforms.com/glossary/ecommerce

[16] K. Y. Vorobyev, Essence of e-commerce in the system of international trade relationships, Russian foreign economic journal 3 (2015) 106-114.

[17] M. Yokoo, T. Ito, M. Zhang, J. Lee, \& T. Matsuo (Eds.) Electronic Commerce: Theory and Practice, Springer Science \& Business Media, vol. 110, Springer, Berlin, 2008.

[18] E. S. Sorokina, O. A. Glazunova, Future development of electronic commerce in Russia, Belgorod State University Scientific Bulletin, Economics Information technologies 7 (204), Issue 34/1 (2015) 58-66.

[19] N. V. Popov, Blockchain technology application in banking: strategic aspect, Journal "Izvestiâ Sankt-Peterburgskogo gosudarstvennogo èkonomičeskogo universiteta" 2 (116) (2019) 152-157.

[20] First digital bank guaranties were given through Masterchain platform (2018), available online: https://

www.vedomosti.ru/press_releases/2018/12/27/naplatforme-masterchein-proshli-pilotnie-sdelki-povidache-tsifrovih-bankovskih-garantii The application data: 01.11.2019

[21] Accenture consulting, Banking on blockchain: a value analysis for investment banks (2017), available 
online:

https://www.accenture.com/t20171108T095421Z__w_ /ph-en/_acnmedia/Accenture/Conversion-

Assets/DotCom/Documents/Global/PDF/Consulting/Ac centure-Banking-on-Blockchain.pdf

[22] B. Carson, G. Romanelli, P. Walsh, and A. Zhumaev, Blockchain beyond the hype: What is the strategic business value? (2018), available online: https://www.mckinsey.com/businessfunctions/mckinsey-digital/our-insights/blockchainbeyond-the-hype-what-is-the-strategic-business-value\#

[23] K. Schwab, The fourth industrial revolution, Crown Business, New York, 2016.

[24] D. L. Rogers, The digital transformation playbook: Rethink your business for the digital age, Columbia Business School Pub., New York, 2016.

[25] KPMG, Digital technologies in Russian companies: survey results, (2019), available online: https://assets.kpmg/content/dam/kpmg/ru/pdf/2019/01/r u-ru-digital-technologies-in-russian-companies.pdf. 